\title{
Marx e a democracia: a apreensão da democracia nas obras da Juventude
}

\author{
Marx and democracy: the capturing of democracy in books by young people
}

\section{Fátima Grave ORTIZ*}

Resumo: $\mathrm{O}$ artigo pretende apresentar algumas considerações quanto ao pensamento de Marx sobre a democracia em suas obras da juventude. Para tanto, recorre à análise de dois livros fundamentais: A Crítica à Filosofia do Direito de Hegel e Sobre a Questão Judaica. Tais obras mostram o desenvolvimento do pensamento de Marx sobre o tema da democracia, do Estado e da política, o que será importante para sua apreensão do funcionamento da sociedade burguesa explicitado nas obras da maturidade, como O Capital.

Palavras-chave: Democracia. Marxismo. Estado. Política.

Abstract: The paper presents some considerations on Marx's thoughts on democracy in his works as a young man. It returns to the analyses two of his fundamental books: Hegel's Critique of the Philosophy of Law and About the Jewish Question. Such books show the development of Marx's thinking on democracy, State and politics, which become important in his capturing of the functioning of bourgeois society explicit in his later books such as Capital.

Keywords: Democracy. Marxism. State. Politics.

Submetido em: 16/4/2018. Revisto em: 12/6/2018. Aceito em: 5/7/2018.

\section{INTRODUÇÃO}

$\mathrm{T}$ ratar a democracia no pensamento de Marx exige uma ampla releitura de algumas de suas obras, sobretudo aquelas conhecidas como juvenis - Crítica da Filosofia do Direito de Hegel, Sobre a Questão Judaica, Introdução à Crítica da Filosofia do Direito de Hegel, Glosas Críticas ao Rei da Prússia. Escritas nos anos de 1843 e 1844, tais obras expressam o diálogo de Marx com a filosofia clássica alemã a partir da crítica às posições teórico-políticas de Hegel, bem como à direita e à esquerda hegeliana.

Neste artigo, optamos por destacar a apreensão e a interlocução do pensamento marxiano com Hegel a partir do resgate das obras supracitadas (especialmente as duas primeiras), além da contribuição de alguns pensadores contemporâneos como Marcuse (2004), Saes (1998) e Enderle (2016) para melhor elucidação do hegelianismo, bem como da apreensão de Marx acerca do pensamento daquele filósofo.

\footnotetext{
* Assistente Social. Doutora em Serviço Social pelo Programa de Pós-Graduação em Serviço Social da Universidade Federal do Rio de Janeiro. Docente da Univ ersidade Federal do Rio de Janeiro/Escola de Serviço Social. (UFRJ, Rio de Janeiro, Brasil). Av. Pasteur, n ${ }^{\circ} 250$ fundos, Botafogo, Rio de Janeiro (RJ), CEP.: 22290240. Pesquisa realizada com apoio do CNPq. E-mail: <fgraveortiz@gmail.com>. ORC ID: <http://orcid.org/oooo-0oo1-8796-0933>.
} 
Além disso, pressupomos que tais obras apresentam a trajetória de Marx como crítico do Estado e da política, bem como sua apreensão da democracia, ora como princípio orientador da emancipação social, ora como movimento necessário ao fortalecimento político da classe trabalhadora.

No entanto, para se apreenderem as posições intelectuais de Marx sobre o Estado, a política e a democracia, é fundamental considerar sua processualidade histórica, isto é, os acontecimentos sócio-históricos europeus do século XIX.

Outro aspecto importante refere-se ao próprio Marx e sua trajetória como pensador. O ano de 1844 foi bastante importante, visto que foi exatamente o período em que Marx elabora algumas de suas obras cujo valor filosófico é de grande importância. São justamente os escritos - Crítica da Filosofia do Direito de Hegel, Sobre a Questão Judaica, Manuscritos Econômico-Filosóficos - desse período que conferem a Marx a apreensão dos fundamentos que lhe permitirão mais de uma década depois realizar a crítica da economia política. O caráter ontológico do trabalho na construção do ser que se torna homem e a identificação da missão revolucionária da classe trabalhadora no processo de construção da emancipação humana, superando a alienação do trabalho e rompendo com o Estado, foram fundamentos centrais no pensamento marxiano.

Nesse sentido, articulado à chamada 135 anos sem Marx, este artigo pretende abordar a concepção de democracia no pensamento de Marx em suas obras juvenis.

\section{MARX E SEU TEMPO HISTÓRICO: O PRIMEIRO ACERTO DE CONTAS COM HEGEL E SUA FILOSOFIA DO DIREITO}

O nascimento de Marx data de 1818 - 200 anos atrás -, ou seja, justamente as primeiras décadas do século XIX em uma Europa marcada pelo que os historiadores chamam de Restauração, que pode ser entendida como um movimento que se desponta na Europa com o declínio do império napoleônico e conduz novamente ao poder monarquias absolutistas, restaurando, desse modo, seu poder político.

Contudo, ainda que o perseguissem, as monarquias da Restauração não conseguiam mais assegurar o controle político e econômico absoluto da época feudal, pois o desenvolvimento das forças produtivas proporcionado pela Revolução Industrial da virada do século XVIII para o século XIX tinha gerado um conjunto de novas relações de produção e, com elas, suas classes fundamentais: burguesia e proletariado. O ano de 1830 foi uma dessas inflexões. Na França, a revolução de 1830 aprofundou a direção burguesa iniciada em 1789, afirmando o poder burguês a partir do fortalecimento político de banqueiros e industriais. Também a partir de 1830, a classe trabalhadora inglesa, engajada no movimento cartista, dá os primeiros passos na direção da luta política e no seu reconhecimento como classe para a superação de seu sofrimento cotidiano (HOBSBAWM, 1996). E a Alemanha?

Embora os servos da gleba houvessem sido libertados em 1807, com grande atraso em relação aos vizinhos (dos países europeus importantes, só Polônia e Rússia ainda mantinham a servidão), o país continuava dividido em dezenas de reinos sob monarcas autocratas, a sua industrialização era não mais que incipiente e a imprensa era mantida sob interminável censura. Era uma terra de filósofos eminentes, racionalis-

Argum., Vitória, v. 10, n. 2, p. 84-96, maio/ago. 2018. 
tas e idealistas (Kant, Fichte, Schelling, Hegel), de poucos operários e nenhuma agitação política (TRINDADE, 2011, p. 28).

Assim, é exatamente com Hegel e com a herança filosófica da qual ele foi um dos protagonistas que Marx dialogou anos depois, inclusive depois da morte de Hegel, que faleceu em novembro de 1831. A obra de Marx Crítica da Filosofia do Direito de Hegel de 1843 inicia esse diálogo e também se revela como uma espécie de acerto de contas com a filosofia clássica alemã, o que só será finalizado com a Ideologia Alemã (1844), em coautoria com Engels.

Contudo, os Princípios da Filosofia do Direito, assim como as demais obras de Hegel, foram lidos de ângulos diferentes pelas chamadas direita e esquerda hegeliana. Para Mascaro,

De um lado estava a direita hegeliana [...], que considerava a racionalidade estatal uma espécie de avanço contra o feudalismo, mas que, paradoxalmente, legitimou um amálgama entre a monarquia prussiana e algumas instituições jurídicas estáveis, na medida em que o poder do Estado não se limitaria por princípios ou valores sociais, pré-estatais. De outro lado, estava a esquerda hegeliana [...], que representava a luta pela atualização alemã em moldes liberais, fazendo com que fossem rompidos definitivamente os laços feudais para que os princípios do direito burguês pudessem, então, vencer. A bandeira da esquerda hegeliana empunhava a modernização aos moldes burgueses liberais e democráticos (MASCARO, 2016, p. 14).

Marx se colocava próximo à esquerda hegeliana, apesar de já apresentar algumas diferenças em relação a esta. Os jovens hegelianos defendiam a democracia, fato que Marx inicialmente também o fazia, apesar de já explicitar certas diferenças entre aqueles que compõem a esquerda hegeliana, como já indicado linhas atrás.

A crítica que Marx efetivou na publicação em 1843 da obra Crítica da Filosofia do Direito de Hegel foi também produto do acúmulo de reflexões acerca das relações materiais existentes. Um exemplo disso diz respeito a sua experiência na Gazeta Renana e à análise que realizou sobre a lei punitiva do roubo de lenha, na qual os pobres eram impedidos de recolher a lenha seca caída das árvores. Nesse artigo, "[...] Marx argumenta contra o rebaixamento da universalidade do Estado e do direito à particularidade da propriedade privada. Em vez de degradar-se ao nível dos interesses privados, o Estado deve submeter esses interesses ao interesse comum, ou seja, ao próprio Estado" (ENDERLE, 2016, p. 21).

Contudo, nesse artigo a pobreza aparece como um problema de ordem política que exige uma solução também política, ou seja, caberia ao Estado, conforme defende Marx, reconhecer juridicamente os costumes dos pobres em recolher a madeira caída das árvores e, desse modo, não tratar essa atitude como furto. Assim, apesar de denunciar o caráter de universalidade do Estado, por ocasião desse artigo ainda permanece em Marx o reconhecimento do Estado como instância acima dos interesses da sociedade civil.

Nestes termos, a argumentação marxiana, mesmo que engenhosa, mostrava-se mais como uma 'acomodação' do que como uma resolução efetiva para a contradição entre Estado e sociedade civil. Ao mesmo tempo em que se distanciava do pensamento hegeliano pela afirmação do direito da classe pobre contra o privilégio da propriedade privada feudal, Marx acabava por reproduzir, com todas as suas consequências, o pressuposto da supremacia ontológica do Estado em relação à sociedade civil, pres-

Argum., Vitória, v. 10, n. 2, p. 84-96, maio/ago. 2018. 
suposto este que acompanhou todo o pensamento político ocidental até alcançar, na filosofia hegeliana, sua forma acabada (ENDERLE, 2016, p. 22).

Cabe ressaltar que, para Hegel, apesar de a humanidade ter alcançado desenvolvimento material capaz de fundamentar a existência da razão e seu papel na sociedade, esta [a sociedade] constitui-se a partir da disputa entre os diversos interesses egoístas dos homens, livres proprietários. Desse modo, segundo Marcuse,

\begin{abstract}
Hegel, entretanto, desde seus primeiros escritos, percebera que as relações de propriedade privada trabalhavam contra a ordem social verdadeiramente livre. A anarquia dos proprietários egoístas não podia produzir, pela sua mecânica, um esquema social integrado racional e universal. Ao mesmo tempo, Hegel sustentava que uma ordem social apropriada não poderia se impor pela negação do direito à propriedade privada, porque com isto o indivíduo livre seria esmagado. A tarefa de executar a necessária integração recaía, pois, sobre uma instituição que pudesse manter os bens individuais e suas relações competitivas, preservando, contudo, os bens e atividades dos indivíduos (MARCUSE, 2004, p. 176).
\end{abstract}

Para Hegel, essa instituição era o Estado, cuja soberania seria capaz de unificar os interesses individuais e gerais presentes na sociedade. A monarquia constitucional seria o meio para garantia dessa soberania. Nesse sentido, o Estado soberano poderia suprimir a competitividade entre os indivíduos, colocando-se acima deles. $\mathrm{O}$ contrato deveria servir apenas para mediar as relações entre os indivíduos, não entre eles e o Estado.

Desse modo, o monarca e a soberania do Estado são dois aspectos presentes na perspectiva hegeliana. O monarca, segundo Hegel, não seria influenciado ou corrompido pelos interesses egoístas dos homens, sendo capaz de "[...] anular toda particularidade na 'simples certeza da sua pessoa”' (MARCUSE, 2004, p. 189).

O que Marx critica em Hegel, e para isso recebe forte influência de Feuerbach, é que Hegel parte do pressuposto de que o Estado é ontologicamente superior à sociedade civil. No entanto, Hegel propõe a conciliação entre Estado e sociedade civil a partir da monarquia constitucional. “O que Marx denuncia como o 'mistério' da especulação hegeliana é a ontologização da Ideia, com a consequente desontologização da realidade empírica. Em Hegel, família e sociedade civil são produzidas pela ideia de Estado, engendradas por ela" (ENDERLE, 2016, p. 25).

Saes (1998), analisando as formulações de Marx sobre o Estado a partir do conjunto das obras da juventude - Crítica da Filosofia do Direito de Hegel (1843), Sobre a Questão Judaica (1843) e Introdução da Crítica da Filosofia do Direito de Hegel (1843-1844) - conclui que, apesar de Marx fazer uma crítica radical à perspectiva hegeliana de Estado, ele não o faz em relação à sociedade civil. No dizer de Saes:

Qual é a posição do Marx de 1843-1844 diante das teses sobre o Estado contidas nos Princípios? O 'jovem Marx' é, sem dúvida, um crítico da filosofia hegeliana da História: e contesta que a dominação da burocracia sobre a sociedade civil - o Estado Moderno, descrito e proposto por Hegel - seja a manifestação da Razão humana. Por isso, defende, não a conservação do Estado moderno, e sim a sua supressão: liquidação da burocracia e dos mecanismos de representação política, instauração de uma 'verdadeira democracia' (=ausência de Estado) onde cada homem seja burocrata e repre-

Argum., Vitória, v. 10, n. 2, p. 84-96, maio/ago. 2018. 
sentante (de si mesmo). É sempre importante relembrar essa crítica, pois ela evidencia a diferença entre o conservadorismo político de Hegel, defensor da preservação do Estado burguês nas suas formas mais reacionárias e antidemocráticas, e o democratismo revolucionário (anarquista) do 'jovem Marx'. Todavia, a relação entre a concepção de Estado contida nos Princípios e aquela presente nos três textos de juventude, já mencionados, não se reduz a essa crítica. Tal relação é na verdade, mais complexa, pois a concepção hegeliana de Estado é, em grande parte, aceita pelo jovem Marx (SAES, 1998, p.55).

Para Marx, o povo deve ser a base da constituição do Estado: “[...] o povo é o 'Estado real”" (ENDERLE, 2016, p. 27); enquanto para Hegel, o Estado é a realização da vontade livre, racional. Na obra hegeliana Princípios da Filosofia do Direito, o Estado supera os estágios abstratos da família e da sociedade civil e se põe como universal concreto. "O Estado é a vontade livre tornada autoconsciente [...] e o fim racional do homem é a vida no Estado" (ENDERLE, 2016, p. 28).

Inspirado profundamente também pelo pensamento de Rousseau, Marx, ao fazer a crítica a Hegel, defende a democracia em oposição à perspectiva hegeliana de soberania do monarca. Há na Crítica da Filosofia do Direito de Hegel dois sentidos para democracia nos escritos de Marx:

[...] como 'gênero' (a 'verdadeira democracia') e como 'espécie' (a 'república política'). A verdadeira democracia é um princípio político, não um Estado existente. Ela significa a realização plena do Estado como universal concreto, a verdadeira superação da oposição entre Estado político e sociedade civil. Na verdadeira democracia, diz Marx, 'o Estado político desaparece', assim como também desaparece o Estado não político, isto é, a sociedade civil. Com o termo 'república política', Marx se refere à democracia no interior do 'Estado abstrato', à democracia existente, ainda não plenamente realizada (ENDERLE, 2016, p. 30).

Desse modo, para Marx a verdadeira democracia possibilita, portanto, ao homem o acesso ao gênero, ou no dizer do próprio Marx: "[...] a verdadeira unidade do universal e do particular" (MARX, 2016, p. 56).

Assim, além de identificar e criticar em Hegel uma concepção idealista de Estado, na qual este possui uma racionalidade acima dos homens, Marx afirma a necessidade da democracia como forma de radicalização, como um caminho possível para a ruptura definitiva com as amarras feudais presentes na sociedade alemã de sua época. No entanto, Marx ainda identifica a possibilidade de transformação da sociedade alemã dentro dos limites do próprio Estado, posição que sofreu inflexões importantes meses depois com a inclusão do texto Introdução à Crítica da Filosofia do Direito de Hegel.

Na Introdução, texto escrito em finais de 1843 e publicado em 1844, Marx avança expressivamente em relação ao seu entendimento anterior publicado na Crítica, pois identifica a classe trabalhadora como o sujeito capaz de empreender a transformação social. Ou seja, a mudança não estaria mais em um rearranjo na estrutura do Estado, mas fora dele.

A 'Introdução' que escreveu à Crítica dá conta de um sujeito histórico específico, que passa a tomar corpo como sendo o cerne da possibilidade de transformação social: a classe trabalhadora. É com base em sua ação política - portanto, a partir do horizon-

Argum., Vitória, v. 10, n. 2, p. 84-96, maio/ago. 2018. 
te dos explorados do capital - que o problema do Estado se reconfigura. Assim, chegando a outra etapa ainda dentro dessa sua primeira fase, Marx anuncia a tomada do Estado pela classe trabalhadora como o grande horizonte crítico da política. Agora a revolução não é mais dentro do Estado e do direito, mas fora deles, empreendida pela classe trabalhadora, passando por eles (MASCARO, 2016, p. 15).

Nas palavras do próprio Marx no texto Introdução, é claro que deve ser a classe trabalhadora a responsável pela construção da emancipação humana; contudo, a Alemanha de seu tempo ainda está limitada à construção da emancipação política, tendo em vista que "o sonho utópico da Alemanha não é a revolução radical, a emancipação humana universal, mas a revolução parcial, meramente política, a revolução que deixa de pé os pilares do edifício" (MARX, 2016, p. 16o). O tema da emancipação política e humana voltaria às preocupações de Marx em outros escritos como Sobre a Questão Judaica, por exemplo.

Assim, conforme Jinkings e Backes:

Na Crítica, Marx afirma a 'verdadeira democracia', no sentido do pensamento de Rousseau (e de Feuerbach). Já na 'Introdução' ele faz uma transição do liberalismo burguês ao tema da 'emancipação humana' (isto é, do comunismo), enquanto a democracia passa a ser identificada com a 'emancipação política'; é quando Marx introduz o conceito de 'democracia acabada' [...], definição que iria muito além da mera transformação da forma política na república burguesa. Ou seja, a 'Introdução' representa uma ruptura de Marx com o seu próprio pensamento inicial, ruptura esta que na Crítica de 43 é apenas anunciada (JINKINGS; BACKES, 2016, p. 8).

A crítica marxiana do Estado e do direito será desenvolvida nas suas obras posteriores como O 18 Brumário de Luís Bonaparte, na qual Marx reconhece que, mesmo que a burguesia não esteja diretamente na gestão do Estado, este ratifica os interesses daquela, possuindo assim um caráter de classe. Mais tarde, em $O$ Capital, ele defende que a forma-mercadoria imprime ao Estado e ao direito a sua forma política e jurídica respectivamente.

\section{SOBRE OS LIMITES DA EMANCIPAÇÃO POLÍTICA E SEUS FUNDAMENTOS: A GUALDADE E A LIBERDADE BURGUESAS}

A aproximação de Marx e seu aprofundamento sobre o tema da política, do Estado e da democracia se colocam a partir do diálogo com a esquerda hegeliana durante os tempos de Gazeta Renana de 1842 a 1843 e Anais Franco-Alemães em 1844.

Em março de 1843, a Gazeta Renana é fechada por intervenção do governo prussiano, no entanto Marx continua a realizar seus estudos, a partir dos quais publica as obras Crítica da Filosofia do Direito de Hegel, no mesmo ano, e a Introdução à Crítica da Filosofia do Direito de Hegel, na virada para 1844. Também em 1843, Marx escreve Sobre a Questão Judaica, no qual faz a crítica ao artigo de Bruno Bauer escrito no mesmo ano e intitulado $A$ capacidade dos atuais judeus e cristãos de se tornarem livres.

Bauer, partícipe do grupo de jovens hegelianos (a esquerda hegeliana), questionava que enquanto os judeus se mantivessem firmes à sua crença religiosa e a todas as obrigações que lhes eram pertinentes, como por exemplo não trabalhar nos dias de sábado, como poderiam exigir do Estado prussiano, que era cristão, a igualdade de direitos? Como queriam ser tidos

Argum., Vitória, v. 10, n. 2, p. 84-96, maio/ago. 2018. 
como iguais se eles mesmos, os judeus, se colocavam de forma distinta na sociedade em função dos ritos religiosos que seguiam? Nas palavras de Marx:

Os judeus alemães almejam a emancipação. Que emancipação almejam? A emancipação cidadã, a emancipação política. [...] O Estado cristão só conhece privilégios. O judeu possui dentro dele o privilégio de ser judeu. Como judeu ele tem direitos que os cristãos não têm. Por que almeja direitos que ele não tem e dos quais gozam os cristãos? Ao querer emancipar-se do Estado cristão, o judeu pede que o Estado cristão renuncie ao seu preconceito religioso. Acaso ele, o judeu, renuncia ao seu preconceito religioso? Teria ele, portanto, o direito de pedir a alguém tal abdicação da religião? [...] Enquanto o Estado for cristão e o judeu judaico, ambos serão igualmente incapazes tanto de conceder quanto de receber a emancipação (MARX, 2010, p. 33).

Para Bauer, para que os judeus alcançassem a igualdade e, portanto, a emancipação, precisavam abrir mão das distinções a que se submetiam em função de sua religião, ou seja, precisavam deixar de ser judeus. O Estado cristão deveria abandonar sua condição cristã e os judeus deveriam deixar de ser judeus. Bauer defende a supressão da religiosidade do Estado e a constituição de um Estado ateu - e do indivíduo. O ateísmo do Estado seria, portanto, uma exigência para Bauer, tal como afirma Marx:

Bauer exige, portanto, por um lado, que o judeu renuncie ao judaísmo, que o homem em geral renuncie à religião, para tornar-se emancipado como cidadão. Por outro lado, de modo coerente, a superação política da religião constitui para ele a superação de toda a religião. $O$ Estado que pressupõe a religião ainda não é um Estado verdadeiro, um Estado real (MARX, 2010, p.36).

Assim, como evidencia Marx, para Bauer o problema não está no Estado em si, mas no fato de ele não ser laico, mas assumidamente cristão. Para Marx, aqui reside o equívoco de Bauer, pois ele não atinge a questão de fundo, que é a própria existência do Estado. Marx reconhece o avanço da crítica feita ao Estado alemão, que não é considerado por ele como um Estado político (ou laico), mas esta ainda é limitada porque reduzida ao caráter teológico.

Marx localiza a religião no âmbito da alienação como uma particularidade desta, o que é claramente afirmado em outras oportunidades, como na Introdução à Crítica à Filosofia do Direito de Hegel. O fato de o Estado se declarar laico não elimina, portanto, a existência da religião, porque esta se localiza como uma necessidade posta efetivamente aos homens, isto é, porque vivem sob condições materiais que necessitam de ilusões, e a religião é uma delas. Marx aponta o exemplo do Estado norte-americano que, mesmo colocando-se como laico, garantiu a liberdade religiosa, não eliminando a religião da vida privada de seus cidadãos. Conforme Marx, naquele país, a religião

[...] foi desbancada para o meio dos interesses privados e degradada da comunidade como comunidade. Todavia não tenhamos ilusões quanto ao limite da emancipação política. A cisão do homem em público e privado, o deslocamento da religião do Estado para a sociedade burguesa, não constitui um estágio, e sim a realização plena da emancipação política, a qual, portanto, não anula nem busca anular a religiosidade real do homem. A dissociação do homem em judeu e cidadão, em protestante e cidadão, em homem religioso e cidadão, essa dissociação não é uma mentira frente à cidadania, não constitui uma forma de evitar a emancipação política, mas é a própria

Argum., Vitória, v. 10, n. 2, p. 84-96, maio/ago. 2018. 
emancipação política; ela representa o modo político de se emancipar da religião (MARX, 2010, p. 42).

Marx ratificava que na ordem burguesa, na qual o Estado deslocou a crença religiosa para o plano privado, garantindo na esfera pública a liberdade religiosa, a religião se manteve mais viva que nunca porque ela consistiu-se em espírito da própria sociedade. Ela fundamenta a própria sociedade, sem incidir sobre o caráter laico do Estado. Assim,

$\mathrm{Na}$ democracia plenamente realizada, a própria consciência religiosa e teológica se considera tanto mais religiosa, tanto mais teológica, quanto mais aparenta ser destituída de relevância política, de propósitos terrenos, quanto mais aparenta ser um assunto do espírito avesso ao mundo, expressão da mentalidade estreita, produto da arbitrariedade e da fantasia, quanto mais for uma vida realmente transcendente (MARX, 2010, p. 45).

Assim, quanto mais liberdade o homem tiver para professar sua religião, sua fé, mais condições terá a religião de exercer seu papel alienador em relação à consciência humana. Nesse caso, a emancipação política por meio da garantia da liberdade religiosa se põe de modo ba stante conveniente à manutenção da sociedade burguesa.

Não estamos, portanto, dizendo aos judeus, como faz Bauer: vós não podeis vos tor-
nar politicamente emancipados sem vos emancipar radicalmente do judaísmo. Es-
tamos lhes dizendo, antes: pelo fato de poderdes vos emancipar politicamente sem
vos desvincular completa e irrefutavelmente do judaísmo, a emancipação política
não é por si a emancipação humana. Se vós, judeus, quereis vos emancipar politica-
mente sem vos emancipar em termos humanos, então a parcialidade e a contradição
não se acham apenas em vós, mas também na essência e na categoria da emancipa-
ção política (MARX, 2010, p. 46).

Desse modo, ainda que o tema da religião fosse importante no debate alemão da época, a crítica de Bauer é limitada porque trata a questão judaica apenas como uma questão religiosa. Marx vai além e identifica que a Alemanha não viveu as revoluções, como a França, apesar de ter assistido e teorizado filosoficamente sobre os processos contrarrevolucionários e restauradores. Expressa, portanto, uma situação anacrônica em relação a outros países europeus. Não bastava mais ser a consciência teórica desses países e seus respectivos processos históricos; a Alemanha precisava avançar, segundo Marx, para além do reconhecimento das liberdades civis e políticas expressas na emancipação política. Era preciso construir a emancipação humana. No dizer de Bensaïd (2010), “[...] diante desse impasse histórico, a simples expansão das liberdades públicas e a 'verdadeira democracia' não são mais suficientes” (BENSAÏD, 2010, p. 15).

Para Marx, a igualdade civil e política entre os homens (emancipação política), que se encontra no âmbito do Estado, é importante, porém limitada, visto que não elimina a desigualdade em si entre os homens. Essa emancipação política deve garantir que todos os homens tenham liberdade de credo, e nesse caso, os judeus não precisavam abrir mão de sua fé; ao contrário. O Estado moderno, cujos principais exemplos estavam na época de Marx nos Estados Unidos e na França, não prescindiu da desigualdade real entre os homens.

A emancipação política do judeu, do cristão, do homem religioso de modo geral consiste na emancipação do Estado em relação ao judaísmo, ao cristianismo, à religião

Argum., Vitória, v. 10, n. 2, p. 84-96, maio/ago. 2018. 
como tal. Na sua forma de Estado, no modo apropriado à sua essência, o Estado se emancipa da religião, emancipando-se da religião do Estado, isto é, quando o Estado não professa nenhuma religião, mas ao contrário, professa-se Estado. A emancipação política em relação à religião não é a emancipação já efetuada, isenta de contradições, em relação à religião, porque a emancipação política ainda não constitui o modo já efetuado, isento de contradições, da emancipação humana. O limite da emancipação política fica evidente de imediato no fato de o Estado ser capaz de libertar de uma limitação sem que o homem realmente fique livre dela, no fato de o Estado ser capaz de ser um Estado livre [...] sem que o homem seja um homem livre (MARX, 2010, p. 38).

Desse modo, enquanto Bauer afirmava que os judeus precisavam deixar a fé judaica para ser emancipados, Marx afirmava que para serem emancipados de fato (e não apenas politicamente) os judeus não precisavam se livrar de sua fé, mas do judaísmo.

Assim, Marx entendia o progresso que a laicidade do Estado, vista em alguns países, trazia aos judeus, mas não entendia que essa fosse a principal questão. Ao contrário, para Marx o problema estava no chamado fetichismo do Estado, ou seja, no entendimento de que o Estado, por ser um ente que arbitra sobre os indivíduos, poderia garantir a liberdade religiosa, tornando os judeus, desse modo, emancipados. No entanto, a garantia dessa liberdade, embora importante historicamente, é insuficiente para a emancipação dos homens.

Os limites da liberdade burguesa, associada à sua congênere igualdade, aparecem em Sobre a Questão Judaica de modo bastante claro. A igualdade jurídica separa o homem do cidadão, porque embora o cidadão em si possua seus direitos, inclusive o de professar sua fé religiosa, a desigualdade entre os homens continua existindo, afinal trata-se de uma sociedade de classes. A igualdade jurídica não se revela como igualdade de fato, igualdade real, apesar de gerar a ilusão de que todos são iguais perante a lei, a única dimensão da igualdade que, na ordem burguesa, realmente importa. Os homens são diferentes realmente, apesar de os cidadãos gozarem juridicamente das mesmas garantias.

O Estado anula à sua maneira a diferenciação por nascimento, estamento, formação e atividade laboral ao declarar nascimento, estamento, formação e atividade laboral como diferenças apolíticas, ao proclamar cada membro do povo, sem consideração dessas diferenças, como participante igualitário da soberania nacional, ao tratar todos os elementos da vida real de um povo a partir do ponto de vista do Estado. Não obstante, o Estado permite que a propriedade privada, a formação, a atividade laboral atuem à maneira delas, isto é, como propriedade privada, como formação, como atividade laboral, e tornem efetiva a sua essência particular. Longe de anular essas diferenças fáticas, ele existe tão somente sob o pressuposto delas [...] (MARX, 2010, p. 40).

Ou seja, o Estado garante as condições jurídico-políticas para a existência de dois homens em um só ser: o homem e o cidadão.

Onde o Estado político atingiu a sua verdadeira forma definitiva, o homem leva uma vida dupla não só mentalmente, na consciência, mas também na realidade, na vida concreta; ele leva uma vida celestial e uma vida terrena, a vida na comunidade política, na qual ele se considera um ente comunitário, e a vida na sociedade burguesa, na qual ele atua como pessoa particular, encara as demais pessoas como meios, degrada a si próprio à condição de meio e se torna um joguete na mão de poderes estranhos a

Argum., Vitória, v. 10, n. 2, p. 84-96, maio/ago. 2018. 
ele. A relação entre o Estado político e a sociedade burguesa é tão espiritualista quanto a relação entre o céu e a terra (MARX, 2010, p. 40).

Do mesmo modo, a liberdade do homem burguês é limitada por aquela de seu semelhante, considerando que a liberdade de um limita a do outro, passando a ser o seu inibidor. Assim, a ampliação da liberdade do homem depende da redução da liberdade do outro, que em situações extremas passa a ser seu inimigo. O direito irá dirimir essa disputa a partir do conjunto de normas jurídicas construídas historicamente.

A liberdade equivale, portanto, ao direito de fazer e promover tudo que não prejudique a nenhum outro homem. O limite dentro do qual cada um pode mover-se de modo a não prejudicar o outro é determinado pela lei do mesmo modo que o limite entre dois terrenos é determinado pelo poste da cerca. Trata-se da liberdade do homem como mônada isolada recolhida dentro de si mesma. [...] o direito humano à liberdade não se baseia na vinculação do homem com os demais homens, mas ao contrário, na separação entre um homem e outro. Trata-se do direito a essa separação, o direito do indivíduo limitado, limitado a si mesmo (MARX, 2010, p. 49).

Desse modo, tomando como referência essa concepção de liberdade, cada homem vê em seu semelhante a restrição da sua liberdade. Assim, a liberdade burguesa não se constrói a partir das relações entre os homens, mas da indicação dos limites estabelecidos entre a liberdade de cada um. Por isso, o complexo da segurança, articulado ao direito, é tão importante. Conforme Marx:

A segurança é o conceito social supremo da sociedade burguesa, o conceito da polícia, no sentido de que o conjunto da sociedade só existe para garantir a cada um de seus membros a conservação de sua pessoa, de seus direitos e de sua propriedade. Nesses termos, Hegel chama a sociedade burguesa de 'Estado de emergência e do entendimento'. Através do conceito de segurança, a sociedade burguesa se eleva acima do seu egoísmo. A segurança é, antes, a asseguração do seu egoísmo (MARX, 2010, p. 50).

Com efeito, Marx identifica claramente em Sobre a Questão Judaica os limites da emancipação política expressa nos marcos da igualdade e da liberdade burguesas, assim como o direito burguês em si e os direitos humanos veiculados pela revolução burguesa. Marx reconhece que na sociedade burguesa o conjunto de direitos humanos, baseado no direito natural, não existe para assegurar de fato ao homem um conjunto de garantias, mas para ratificar o direito do homem burguês. Na verdade, a própria concepção de indivíduo, apesar de um avanço em relação ao Antigo Regime, não fortalece a individualidade como uma dimensão do gênero humano (do ser genérico), mas o individualismo, que apartado do gênero, move-se de forma egoísta e fragmentada em relação à totalidade, aprofundando ainda mais a distância social entre os homens. A crítica de Marx à concepção burguesa de direitos humanos se põe como uma denúncia a essa concepção de indivíduo. Assim, para Marx,

[...] nenhum dos assim chamados direitos humanos transcende o homem egoísta, o homem como membro da sociedade burguesa, a saber, como indivíduo recolhido ao seu interesse privado e ao seu capricho privado e separado da comunidade. Muito longe de conceberem o homem como um ente genérico, esses direitos deixam transparecer a vida do gênero, a sociedade, antes como uma moldura exterior ao indivíduo, como limitação de sua autonomia original. O único laço que os une é a necessidade

Argum., Vitória, v. 10, n. 2, p. 84-96, maio/ago. 2018. 
natural, a carência e o interesse privado, a conservação de sua propriedade e de sua pessoa egoísta (MARX, 2010, p. 50; grifos nossos).

Desse modo, apesar de Marx não ser insensível às demandas por emancipação política reivindicada pelos judeus, o autor identifica limites que lhes são intransponíveis, os quais residem na própria estrutura de classes da sociedade burguesa, que inviabiliza qualquer tentat iva de construção de uma verdadeira igualdade, liberdade e até de democracia. Portanto, “[...] a emancipação política é a redução do homem, por um lado, a membro da sociedade burguesa, a indivíduo egoísta independente, e, por outro, a cidadão, a pessoa moral" (MARX, 2010, p. 54).

Esse entendimento está claro na Introdução à Crítica da Filosofia do Direito de Hegel, quando Marx atribui à classe trabalhadora a missão revolucionária de transformação da sociedade. Em Sobre a Questão Judaica, o reconhecimento da classe trabalhadora ainda não é efetivamente explícito, apesar de já se anunciar a necessidade de superação da cidadania abstrata que as concepções de igualdade e liberdade burguesas fundamentam para a constituição da emancipação humana. No dizer do próprio Marx:

Mas a emancipação humana só estará plenamente realizada quando o homem individual real tiver recuperado para si o cidadão abstrato e se tornado ente genérico na qualidade de homem individual na sua vida empírica, no seu trabalho individual, nas suas relações individuais, quando o homem tiver reconhecido e organizado suas 'forces propres' [forças próprias] como forças sociais e, em consequência, não mais separar de si mesmo a força social na forma de força política (MARX, 2010, p.54).

Assim, Marx reconhece que a emancipação política é um avanço, e principalmente que é o único avanço possível dentro da ordem burguesa, ou seja, a garantia da igualdade e da liberdade burguesa, e de tudo o que essas significam, expressa o ponto de máximo que judeus e não-judeus podem alcançar na ordem capitalista.

A emancipação política de fato representa um grande progresso; não chega a ser a forma definitiva de emancipação humana em geral, mas constitui a forma definitiva da emancipação humana dentro da ordem mundial vigente até aqui. Que fique claro: estamos falando aqui da emancipação real, de emancipação prática (MARX, 2010, p. 41; grifos meus).

Além disso, Marx mantém a referência à verdadeira democracia, que também aparece em Sobre a Questão Judaica como meio para a construção da emancipação humana. Conforme Bensaïd:

Não se trata de negar a importância da emancipação política, mas de ultrapassar seus resultados conservando-os, de caminhar rumo à 'verdadeira democracia', que, desde a Crítica da Filosofia do Direito de Hegel, faz a ponte entre o liberalismo renano e a revolução radical. [...] A 'verdadeira democracia' é a 'autofundação continuada' da política e do social. [...] Associada ao perecimento do Estado, a 'verdadeira democracia' não seria então o 'deflagrador revolucionário de um instante', ou 'uma curiosidade sem dia seguinte' na obra de Marx, mas realmente a 'matriz antiestatal' persistente que corre sob os remanejamentos conceituais sucessivos (BENSAÏD, 2010, p. 87).

Argum., Vitória, v. 10, n. 2, p. 84-96, maio/ago. 2018. 


\section{CONSIDERAÇÕES FINAIS}

Podemos observar, através da análise das obras juvenis, como o acúmulo teórico, mas ta mbém político, realizado por Marx lhe permitiu aprimorar suas posições teóricas em relação à temática democrática, sem que isso pudesse conferir a esse processo algum tipo de desmerecimento intelectual ou político. Em vez disso, é possível verificar que Marx foi estimulado pelo conjunto de contradições de sua época, fazendo-lhe transitar, em um relativo e curto espaço de tempo, de uma posição ainda restrita aos limites do Estado para a defesa da sua completa superação.

Quando Marx faz a crítica ao pensamento hegeliano, ele o faz do ponto de vista ontológico, uma vez que discorda de que o Estado possa ser a manifestação da razão humana, como nos lembra Saes (1998). Ao contrário, diante da real situação que envolveu o caso do roubo de lenha, Marx identifica o flagrante posicionamento do Estado em favor dos proprietários de terra em detrimento da existência de necessidades humanas concretas. Tal postura denuncia, no entendimento de Marx, a impossibilidade efetiva de ser o Estado portador da razão humana.

Entretanto, ainda que não lhe seja claro o caráter de classe do Estado (pelo menos não ne sses termos), Marx reconhece a necessidade da instauração de uma verdadeira democracia. Nesta, “[...] o próprio Estado é apenas uma autodeterminação e um conteúdo particular do povo, na medida em que esse conteúdo é constituição política” (MARX, 2016, p. 57). A necessidade de superação do Estado apenas ficará mais evidente para Marx a partir da Introdução à Crítica da Filosofia do Direito de Hegel e depois com Sobre a Questão Judaica.

Nesse último, inclusive, enquanto Bauer não pressupõe que o problema de fundo que se põe para os alemães de sua época é a existência do próprio Estado, Marx reconhece que a garantia da liberdade religiosa em si não possibilita a emancipação plena, mas, na melhor das hipóteses, a emancipação política, concluindo que a manutenção do Estado, e com isso a verdadeira democracia, poderá pavimentar o caminho, mas não poderá se converter em finalidade para o desenvolvimento pleno dos homens.

Com efeito, é clara a importância das obras juvenis para o pensamento marxiano, sobretudo em relação ao aprimoramento teórico experimentado anos mais tarde com a publicação de O Capital, mas também em relação ao aprimoramento explicitamente político, que articulado com a experiência de Engels, culminou ainda nos anos 40 do século XIX com o Manifesto do Partido Comunista (1848). Nessas obras, a temática do Estado, da política e da democracia toma rumos mais claros, tendo em vista que Marx não lhes concede mais qualquer ilusão; ao contrário, a emancipação humana exige a supressão do Estado e da própria política.

No entanto, o tema da democracia, tão caro e ao mesmo tempo tão polêmico, é retomado pelas esquerdas mundiais no século XX como caminho para o socialismo e, desse modo, como subsídio central para projetos partidários no mundo e no Brasil, debate necessário e sempre relevante a se retomar, sobretudo em tempos tão sombrios e turbulentos no caso brasileiro e mundial.

Argum., Vitória, v. 10, n. 2, p. 84-96, maio/ago. 2018. 


\section{REFERÊNCIAS}

BENSAÏD, D. Apresentação. Pósfacio. In: MARX, K. Sobre a questão judaica. São Paulo: Boitempo, 2010.

ENDERLE, R. Apresentação. In: MARX, K. Crítica da Filosofia do Direito de Hegel. 3. ed. São Paulo: Boitempo, 2016.

HOBSBAWM, E. A era das revoluções. 9. ed. Rio de Janeiro: Paz e Terra, 1996.

JINKINGS, I.; BACKES, M. Nota à primeira edição In: MARX, K. Crítica da Filosofia do Direito de Hegel. 3. ed. São Paulo: Boitempo, 2016

MARCUSE, H. Razão e revolução: Hegel e o advento da teoria social. 5. ed. Rio de Janeiro: Paz e Terra, 2004.

MARX, K. Crítica da Filosofia do Direito de Hegel. 3. ed. São Paulo: Boitempo, 2016.

MARX, K. Sobre a questão judaica. São Paulo: Boitempo, 2010.

MASCARO, A. L. Prefácio à terceira edição In: MARX, K. Crítica da Filosofia do Direito de Hegel. 3. ed. São Paulo: Boitempo, 2016.

SAES, D. Estado e democracia: ensaios teóricos. 2. ed. Campinas: UNICAMP, 1998.

TRINDADE, J. D. de L. Os Direitos humanos na perspectiva de Marx e Engels: emancipação política e emancipação humana. São Paulo: Alfa-Ômega, 2011.

\footnotetext{
Fátima Grave ORTIZ

Doutora em Serviço Social pelo Programa de Pós-Graduação em Serviço Social da Universidade Federal do Rio de Janeiro. Mestre em Serviço Social (UFRJ). Docente da Universidade Federal do Rio de Janeiro/Escola de Serviço Social. Pesquisadora do Núcleo de Estudos e Pesquisas sobre os Fundamentos do Serviço Social na Contemporaneidade (NEFSSC). Integrou o Comitê de Ética em Pesquisa do Centro de Filosofia e Giências Humanas da UFRJ. Foi conselheira do Conselho Regional de Serviço Social 7a. região nas gestões 2005-2008 e 2008-2011, ocupando nesta última o cargo de conselheira presidente. Foi coordenadora nacional de pós-graduação da ABEPSS (gestão 2015-2016). É atualmente VicePresidente Regional da ABEPSS pela Regional Leste (2017-2018).
}

Argum., Vitória, v. 10, n. 2, p. 84-96, maio/ago. 2018. 